\title{
Pedagogical aims, course characteristics and their relation to students behavior: A case study on blended learning
}

\section{Sven Grund and Gudela Grote}

An exploratory blended learning case study in corporate finance is presented. A detailed description of the actual use of different training materials (books / simulations / self-assessing) and scenarios (online / offline / individual / group learning) is given. This was one of the first blended learning studies integrating different evaluation methods into a systematic user behavior analysis approach. A sample of one hundred sixty one students filled in a user profile questionnaire, used an online diary after each system log out to describe their user behavior, passed a final exam and answered an exams preparation questionnaire. Furthermore we collected log file data. The results show that students preferred to study during the semester and for the exams preparation with papers, self-assessment tasks and Excel-simulations rather than to use interactive discussion forums. We conclude that future blended learning developments should focus on interactive material, clearly link multiple-choice test tasks with the final exam and train students to use blended learning concepts efficiently.

\section{Introduction}

When computers were introduced into classrooms, new multimedia technologies started to enrich teaching- and training-material. Researchers and practitioners asked themselves how to integrate picture / text / video / animation / simulation into courses to achieve better learning results. Many individual computer based materials were developed and tested. Soon the question about the comparison of traditional face-to-face versus Computer Based Training "CBT» was raised. The learning benefits of new learning settings were generally much smaller than expected (Russell, 1999). A further step was achieved by integrating internet technology and personal computers leading to Web Based Training «WBT» courses integrating distributed communication and cooperation opportunities into teaching and training.

The capability of these learning technologies can be described as follows (Mandl \& Reinmann-Rothmeier, 2000): 
- realising self-organized learning;

- fostering problem-based learning;

- guiding and stimulating cooperative learning;

- guaranteeing instructional guidance and support.

Nowadays, new learning tools offer opportunities for limitless combinations of different types of learning materials (e.g. Flash-animations, PDF files, hypertexts, simulations) and learning settings (e.g. individual learning, face-to-face or distributed group learning). Such combinations are called blended learning (Horton, 2000). eLearning and face-to-face settings are linked to make learning more efficient and interesting (Kerres, 2002; Scholz, 2002). Blended learning involves the notion of hybrid learning, where a new kind of learning situation is created. An important aspect is the mixture of individual, computer-supported learning and social learning in groups.

Research activities in new learning media focus on three different learning settings:

1. individual on / offline eLearning (see Trier, 1999);

2. computer supported cooperative learning «CSCL» versus face-to-face group learning (see Lethinen, Hakkarainen, Lipponen, Rahikainen \& Muukkonen, 2002);

3. blended learning (see Reinmann-Rothmeier, 2003).

In the context of learning settings research was carried out in the preparation of learning material presented to students, e.g. effective text / picture (Cooper, 1997), audio / visual (Mousavi, Low \& Schweller, 1995) mixture, integration of haptic information in the learning material (Grund \& Grote, 1999) or two dimensional versus three dimensional pictures (Dede, Salzman, Loftin \& Sprague, 1999). This research focuses on effects of multicodality and / or multimodality on learning benefit (Weidenmann, 1997).

CSCL and group learning research are related to the kind of instruction (distributed instruction, problem-based instruction versus blackboard or group instruction) which are given to students (e.g. Bain, 2003).

Blended learning research studies are scant. A first, complex blended learning evaluation was presented by Reinmann-Rothmeier (2003). The course consisted of a CD-ROM with individual learning material, basic support for cooperative work «BSCW ${ }^{\circledR}$ » as a collaboration tool and online problem-based tasks. A preknowledge test as well as pre- and post-questionnaires were delivered to the students and some observations were taken. Reinmann-Rothmeier states that blended learning activities can involve innovation in training and teaching at universities.

Different books (e.g. Sauter, 2002) and articles (Scholz, 2002; Valiathan, 2002) describe how to set up blended learning courses. Looking at the theoretical background of blended learning presented in the citied articles above one rea- 
lizes that it is assumed that blended learning leads to synergistic effects. Nevertheless, this assumption is not backed by consistent theoretical and empirical evidence. This might be due to the fact that the concept is mainly derived more from practical experiences and recommendations from companies (ReinmannRothmeier, 2003). Blended learning experiences are often presented at the level of best practice examples based on limited systematic research or analytic approaches.

The theoretical foundation of blended learning consists of theories developed for different learning settings (see Table 1).

\section{Table 1: Theoretical aspects of blended learning}

\begin{tabular}{|c|c|c|}
\hline Learning setting & Theoretical background & Didactical implications \\
\hline $\begin{array}{l}\text { Autonomous learning: Student is lear- } \\
\text { ning alone in front of the computer } \\
\text { or with paper and pencil. }\end{array}$ & $\begin{array}{l}\text { Programmed learning (Skinner, 1958) } \\
\text { Self-organized learning (Zimmer, } \\
1990)\end{array}$ & $\begin{array}{l}\text { Clear learning objectives, modular } \\
\text { course design, learning paths, multi- } \\
\text { media enriched training material. }\end{array}$ \\
\hline $\begin{array}{l}\text { Group learning and discussion } \\
\text { groups: } \\
\text { Students work together face-to-face } \\
\text { or virtually, sometimes with coaching } \\
\text { assistance. }\end{array}$ & $\begin{array}{l}\text { Constructive learning (Edelmann, } \\
1996) \\
\text { Expansive learning (Engeström, } \\
\text { 1999) } \\
\text { Situated learning (Greeno, 1997) }\end{array}$ & $\begin{array}{l}\text { Learning in groups, working with } \\
\text { case studies which contain a certain } \\
\text { amount of constraints and affor- } \\
\text { dances. }\end{array}$ \\
\hline $\begin{array}{l}\text { Class attendance: } \\
\text { Students are sitting in a large class- } \\
\text { room and get instructions from a pro- } \\
\text { fessor. }\end{array}$ & $\begin{array}{l}\text { Instructional design theory (Reige- } \\
\text { luth, 1999) } \\
\text { First principles of instruction (Merill, } \\
\text { 2002) }\end{array}$ & $\begin{array}{l}\text { Activation of prior experience, de- } \\
\text { monstration of skills, application of } \\
\text { skills, integration of these skills into } \\
\text { real world activities. }\end{array}$ \\
\hline
\end{tabular}

Together they form a kind of patchwork. The underlying concepts are either based on behavioural, cognitive or constructivist assumptions. Bain (2003) reflected these assumptions in the context of eLearning. He concludes that a pure constructivist approach seems to be limited and that an integration of guided and self-organized constructive learning would be more appropriate to foster learning processes. This is a fundamental argument to encourage blended learning course designs. One can imagine that autonomous learning, group learning and class attendance all require a different level of competence in self-organisation, motivation, media experience and social competence as described by Reinmann-Rothmeier (2003). The integration of different learning situations into a course leads to even higher needs for competence.

So, students who are confronted with a blended learning course might be challenged in organizing their learning as long as different learning paths, methods and settings are available. Friedrich (2000) differentiates the following aspects of decisions that must be taken for self-organized learning to be accomplished:

- Learning goals: On what?

- Learning content: What?

- Method: How?

- Media: With what? 
- Time: When?

- Evaluation: How good?

Additionally, learning at a university is not an end in itself. Finally students must pass an exam in order to achieve an academic degree. This accreditation will be reached by accomplishing a predefined number of European Credit Transfer System «ECTS»-points in different courses, lectures, workshops, tutorials, excises etc. Thus, students try to optimize their learning activities. In general learning situations can be described on a continuum from highly self-organized to strongly externally-controlled (Friedrich, 2000). Grote (1997) uses the concept of autonomy in socio-technical systems to describe the freedom in defining objectives and rules to achieve these objectives. Autonomy at lower levels takes place with respect to: working content characteristics (1) and working conditions (2); autonomy at higher levels occurs at a higher level of abstraction: (3) pupils are enabled to restrict their individual autonomy to increase collective autonomy.

Each blended learning course offers students a specific type of working (learning) content characteristic. For example, students have no influence in defining learning content, which is mostly predefined in the course specification, but they can define actions to be taken (e.g. ways of learning by using books or exercises for task accomplishment). In many cases students have freedom with respect to learning time and learning quality. Since blended learning offers a variety of learning media and material students can choose between many options.

In class attendance situations autonomy is strongly restricted as long as the professor is responsible for learning content, used media etc. In group learning or group discussions, individual autonomy can be limited by the collective autonomy. For example, the topic to be discussed or the work intensity on a certain task might be defined within the group.

The gaps in the empirical literature on blended learning and the patchwork of theories guided us to be focus on student's self-organisation (choosing training settings and material), when different learning opportunities were available (autonomous learning with a guiding path and free exploration, group learning and class attendance).

Each learning setting was theoretically grounded, as described previously. Students were not pedagogically forced (reduced control of the teacher) to make use of the learning opportunities. However, they were informed about the particular purpose of each learning opportunity and encouraged to make use of these opportunities.

\section{Research questions}

In this project we were mainly interested in following explorative questions:

- How do students make use of their learning autonomy in a blended learning course? 
- When do students learn?

- Which learning materials will be mainly used by students?

- Which training settings are appreciated?

- Which materials / settings are used for exam preparation?

- Are group activities related to the final exam score and are there relations between individual's task performances during the semester and the final exam score?

Our aim was to introduce some empirical insights into a blended learning course in order to gain an understanding of the relationship between pedagogical aims, course characteristics and students' self-organization. Our ultimate goal was to pinpoint the innovative aspects and pitfalls of a blended learning course design. Additionally, we derived practical recommendations from our findings.

\section{Methods}

In the following section, the Concept and Instruments for Evaluation of Learning Tools "CIELT» (Grund, Grote \& Windlinger, 2003) is described to provide a basis for the development of a blended learning course evaluation. Afterwards a detailed description of a blended learning course is presented, followed by an overview of an implemented evaluation design.

\section{CIELT}

The CIELT framework was applied in this exploratory study. CIELT has been applied within several eLearning projects and it has been shown to adequately support the evaluation of usability, user behavior, learning process and outcome (Grund, Grote \& Windlinger, 2003). CIELT was developed mainly based on the socio-technical systems approach. In comparison with purely analytical approaches, CIELT focuses on system design processes as well as on providing adequate conditions for enabling the work system's primary task (e.g. Emery, 1959; Grote, 1997). The task of a work system (e.g. students working in distributed teams on a learning task) is considered as the core of interaction between organization and technology, linking working or learning individuals with technological conditions and the organizational framework for task fulfillment. Thus CIELT provides a methodological framework to define design goals (e.g. technical requirements, pedagogical and didactic objectives), choose useful instruments and evaluate the goal fulfillment as well as analyzing changes in the organization of the work system into which the new technology and new pedagogical approaches are introduced. 


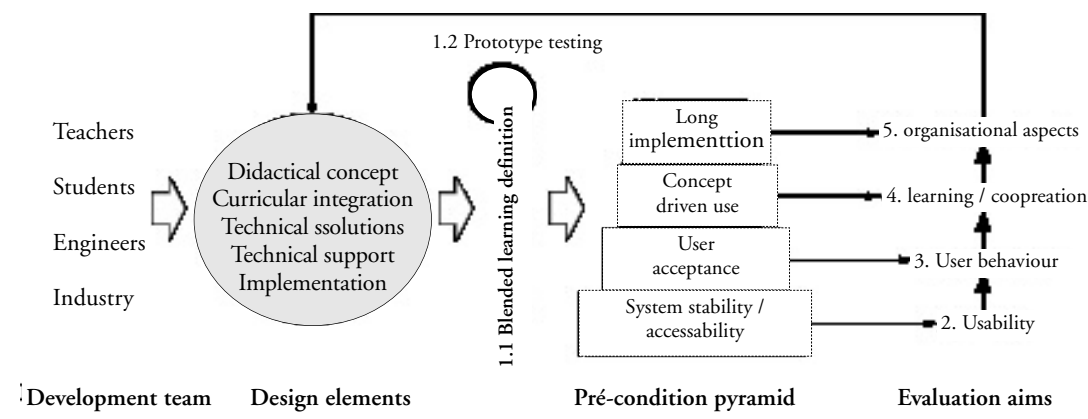

Figure 1: Concept and Instruments for Evaluation of Learning Tools «CIELT»

Figure 1 shows an overview of CIELT. The concept is based on an iterative learning system development approach with formative and summative evaluation elements. The feedback loop implies that after each analysis step (1.1 to 5) results are used to improve design elements, which then again lead to a new blended learning system definition. The hierarchical structure of the pre-condition pyramid should not be misunderstood as a static and impermeable process visualization. For example, user behavior can be analyzed without a previous usability test. It only emphasizes that evaluation of higher levels can be carried out more appropriate when different preconditions are fulfilled.

On the left side of the figure, possible interest groups in the development team are listed, displaying the potential heterogeneity of such teams. Core design elements such as didactical concept, curricular integration and technical implementation are described, which must be integrated in order to define a blended learning system (1.1). The following evaluation steps are based on Kirkpatrick (1987) who differentiated four levels of evaluation: reaction, learning, behavior and organization.

The prototype testing (1.2) focuses on usability and is the first step in an evaluation process, setting the stage for any real world application of the system. For the following steps in the evaluation process, the pre-condition pyramid should be considered. The pre-condition pyramid points out different requirements that need to be fulfilled for evaluating specific aspects of a blended learning system.

In order to evaluate usability (2), the system needs to be accessible and stable. If this is not the case, usability can not be examined properly. To develop a user friendly system is of major importance because it strongly influences the future system use (Nielsen, 1994).

In order to examine user behavior (3), the system must be accepted by the users / learners. Concept driven use and long term implementation are requirements for evaluating learning process and learning outcomes (4). A case study 
showed that students' perception of cooperation is not related to actual cooperation (Grund, Gerber \& Grote 2003). The importance of organizational aspects (5) in the context of educational systems was shown by Cuban (2001). He pointed out three major aspects that should be taken into account: (I) technology changes take far longer to implement in formal education than in businesses because schools, at least in Europe, are mostly government-controlled nonprofit organizations; (II) historical, social and political contexts of teaching imply that schools perform a social role in a democracy; (III) historical traditions in school structures and activities are another dimension which often has to be taken into account.

The CIELT concept was used to develop an evaluation design for the electronic Corporate Finance «eCF» blended learning course as described below.

\section{Blended Learning course electronic Corporate Finance «eCF»}

The electronic Corporate Finance blended learning course concept has been designed to replace a classical face-to-face lecture ( 4 hours per week for one semester) and is continuously modified. The course content is stored in eCF-Basic and BSCW® is used as collaboration platform. eCF-Basic allows students to learn independently from time and place. Students must invest up to 180 hours to pass the course including exam preparation in order to achieve 6 European Credit Transfer System «ECTS»-points. The nine content modules are subdivided into three to four learning units.

At the beginning of a semester, two introductory lectures are held to introduce the new learning and working methods of blended learning, to identify learning groups and to provide technical information about the system components.

During the whole continuous autonomous learning (15 lectures), an onlineLearning path guides students through the learning material. It displays the methodological structure of the learning material and it can be used by students as a guide. Elements of autonomous learning include reading assignments for individual knowledge acquisition, exercises (Excel-simulations, Flash-animations) for knowledge use and application as well as self-assessments (multiple-choice questions). Additionally, a database provides a direct and self-controlled access to the entire course content. The database consists of a media pool, providing access to all learning materials as well as a multimedia glossary with search capabilities by course relevant terms. Furthermore, students must solve a maximum of seven individual test tasks and one group task to achieve a minimum of 30 points out of 45 points to be accredited to the final exam. The group task is a detailed case study which requires group working and learning.

Students get support for content as well as social and administrative issues related to the course via online coaching. Students are divided into twelve groups of 24 students maximum. Each group is supported by an online-coach. The coach 
encourages discussions in the online forums every week by posting questions, answering student's questions and giving feedback on test tasks. The basic documentation for the online-coach is the coaching handbook. It was developed according to Salmon's (2000) guidelines about e-moderating. It contains all the necessary information and instructions for completing the coaching duties.

The periodic class attendance (5 lectures), approximately every second week, helps students to discuss difficult units in depth and prepare for the final exam with the professor.

Figure 2 gives a brief overview of the eCF-blended learning course concept.
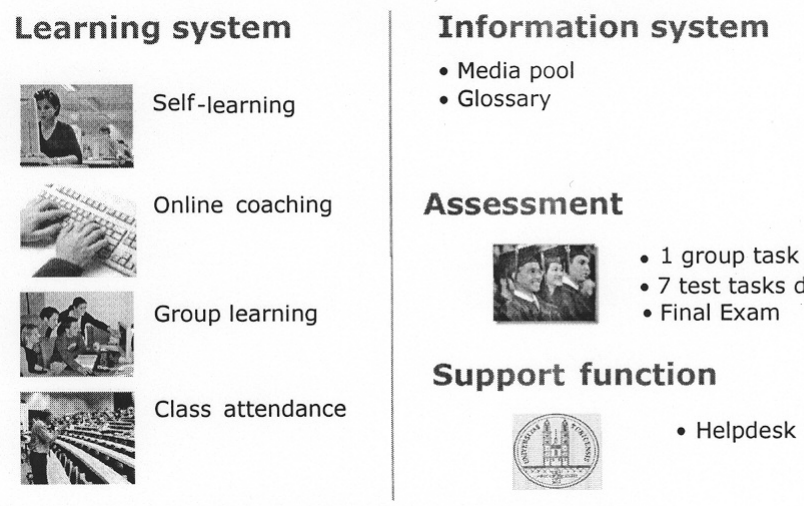

Figure 2: eCF-blended learning course concept

The eCF evaluation includes four development phases and evaluative iterations:

1. First prototype test on CIELT level 2 focusing on usability issues. Twelve students used the system over a period of one week and answered a detailed questionnaire dealing mainly with usability issues (summer 2001).

2. Second prototype test with 196 students on CIELT level 2 (usability issues) and 3 (user behavior) using the system within in the curriculum for five weeks (winter 2001/02).

3. Final system evaluation on CIELT level 2 (usability issues), 3 (user behavior) and 4 (learning and cooperation). One hundred sixty one students participated one semester in the eCF-course (winter 2002/03).

4. For quality insurance, a continuous evaluation with a reduced set of instruments was implemented (winter 2003/04).

After each phase, measures of improvement were developed and implemented in the next system and course development phase. Detailed information can be found in Grund, Windlinger and Grote (2002) and Grund, Gerber and Grote (2003). In this article results of the third evaluation phase will be presented. 


\section{Instruments}

To understand students' use of a blended learning system and the system's impact on learning outcome we based the evaluation on variables from individual learning, on / offline learning, CSCL and blended learning. The eclectic choice of variables is due to the fact that only few sophisticated blended learning studies are available for user behavior analysis.

For students, previous computer experience (Sturgill, Martin \& Gay 1999) is of major importance for working in WBT settings. Also, students' attitude toward a medium (Weidenmann, 1993) is related to media use. For these reasons, a questionnaire with socio-demographic data (gender, age, place of living and major field of study), attitudes toward computer and internet, previous experience with computer, internet, software, CSCL, equipment and internet access at home and learning tool / method preferences was developed.

In many studies, only subjective data have been collected in order to describe students' interactions and their relationship to subjectively rated learning outcomes (e.g. Shea, Fredericksen, Pickett, Pelz. \& Swan, 2000; Swan, Shea, Frederickson, Picket, Pelz \& Mahler, 2000 or for an overview Brink \& Windlinger, 2000). However, Friedrich and Mandl (1997) strongly suggest focusing on what is happening in a learning situation, for example by using learning diaries. Therefore, student behavior was measured using: (1) an online log out diary, which was filled in after system log out and which took all online and offline learning materials and activities into consideration. Students described what they did online, their amount of actions and approximated time to carry out these actions. Additionally, they described their offline activities since the last online system use, e.g. reading the text book or working on a group task. (2) Log files were gained from each student. (3) An exam preparation questionnaire covering all learning opportunities was delivered right after the exams. Students were asked to describe how intensively they used different types of learning material, e.g. summaries, Excel-simulations or texts for the exams preparation, on a 7 point scale.

The impact of technology on learning processes and outcomes has been discussed controversially for more than a decade by Richard Clark (1994, 2001), who argues that media will never influence learning, and by Bob Kozma (1991, 1994), who counters that media will influence learning in the future. It is not our intention to continue this discussion. From an empirical point of view, a final conclusion is difficult. However, some observations should be made. In particular, if nowadays authors such as Kerres (2002) or Reinmann-Rothmeier (2003) speak of added values in blended learning, a differentiated effect analysis is indispensable.

For eLearning, which is only one aspect of blended learning, benefits are empirically discussed as the "no significant difference phenomenon» in eLearning (Russel, 1999). As long as blended learning is a mixture of different learning settings and materials, we are interested in the effects on learning outcome. Lear- 
ning outcome was continuously measured via seven individual tests, one group task during the semester and a final paper and pencil exam.

The first study about the relationship between communication activities and final exam scores taking real behavior into consideration was conducted by Picciano (2002). To answer our research questions, we also measured the interaction between students / coaches based on $\mathrm{BSCW}{ }^{\circledR}$ postings and e-mails sent to a student / coach.

Coaching activities were described in a coaching diary and in a coaching evaluation questionnaire which was delivered at the course end.

The following Table 1 shows the different instruments related to the eCFcourse evaluation. A detailed description of all results can be found in Grund, Gerber \& Grote (2003). We will focus on results related to student's self-organization (learning behaviour) and learning outcome.

Table 2: eCF-course evaluation design

\begin{tabular}{|l|l|l|l|l|l|}
\hline & Pre test & Process & Post test 1 & Post test 2 & Post test 3 \\
\hline Time & $\begin{array}{l}\text { In the first course } \\
\text { week }\end{array}$ & $\begin{array}{l}14 \text { weeks training } \\
\text { Students }\end{array}$ & $\begin{array}{l}\text { At the end of the } \\
\text { course }\end{array}$ & $\begin{array}{l}\text { One week after } \\
\text { the course }\end{array}$ & $\begin{array}{l}\text { Right after the } \\
\text { exams }\end{array}$ \\
\hline questionnaire & $\begin{array}{l}\text { Students' beha- } \\
\text { vior } \\
-\log \text { file data } \\
-\log \text { out diary } \\
-7 \text { individual test } \\
\text { tasks } \\
-1 \text { group task }\end{array}$ & $\begin{array}{l}\text { Course evaluation } \\
\text { questionnaire } \\
\text { including } \\
\text { usability }\end{array}$ & $\begin{array}{l}\text { Learning } \\
\text { Final exam }\end{array}$ & $\begin{array}{l}\text { Exams } \\
\text { preparation ques- } \\
\text { tionnaire }\end{array}$ \\
\hline $\begin{array}{l}\text { Interaction } \\
\text { Students / } \\
\text { Coaches }\end{array}$ & $\begin{array}{l}\text { BSCW® postings } \\
\text { E-mails }\end{array}$ & Coaching diary & $\begin{array}{l}\text { Coaching } \\
\text { évaluation } \\
\text { questionnaire }\end{array}$ & & \\
\hline Coaches & & \multicolumn{3}{l}{} & \\
\hline
\end{tabular}

Students' profile

One hundred sixty one students participated in evaluation phase three (39 women and $122 \mathrm{men})$. The average age was 24 years $(\mathrm{SD}=2.9)$. The students had nine years $(\mathrm{SD}=3.6)$ of computer experience. They rated their computer competence, on a scale from 1 «no experience» to 100 «very high experience / expert», with 67 points as an average $(\mathrm{SD}=16)$. Two thirds of the students had no experience with CBT and WBT. 57\% had only worked once with computer supported cooperation tools such as BSCW® or OLAT(r) and $22 \%$ had no experience at all. Internet browsers were used daily, word processor and spreadsheet weekly. Most of the students (98\%) used Windows computers. Everybody had access to the internet from home. Of all students $69 \%$ used an ISDN or an even faster internet connection from home. They spent about seven hours per week on the internet, with three hours related to study activities. These results suggest that students had sufficient media experience in order to pass the blended learning course. 


\section{Results}

In the results section, students' behavior, including communication and collaboration activities, are analyzed. Finally, major impact factors on the final exam scores are presented.

\section{Students' system use}

Question: When do students learn?

The log files (see Figure 3) show that students worked at all hours of the day. The main online activities took place between 9 AM to 6 PM.

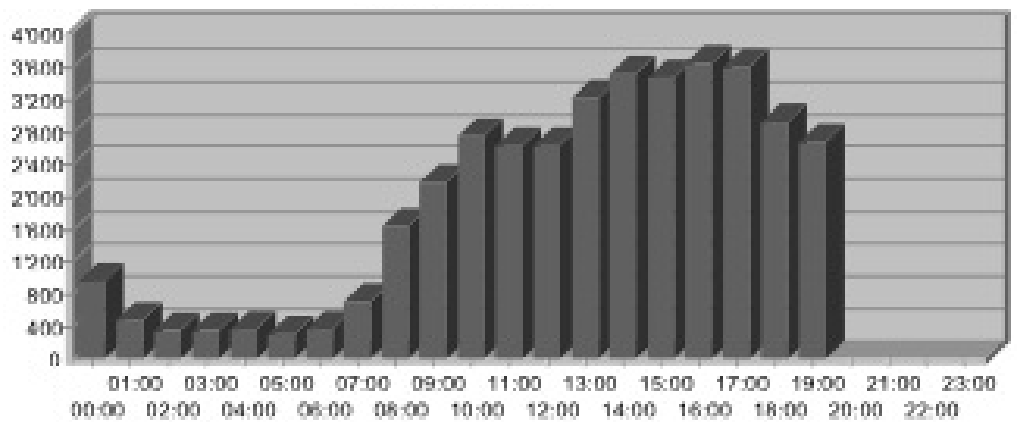

Figure 3: eCF-Basic / BSCW® log-ins accumulated over the semester

The activities summarized by days decreased from approximately 8000 log-ins on Monday to $4800 \mathrm{log}$-ins on Saturday. During the semester a decrease of online activities was found (see Figure 4). Students visited the collaborative area BSCW® approximately during every second system entry.

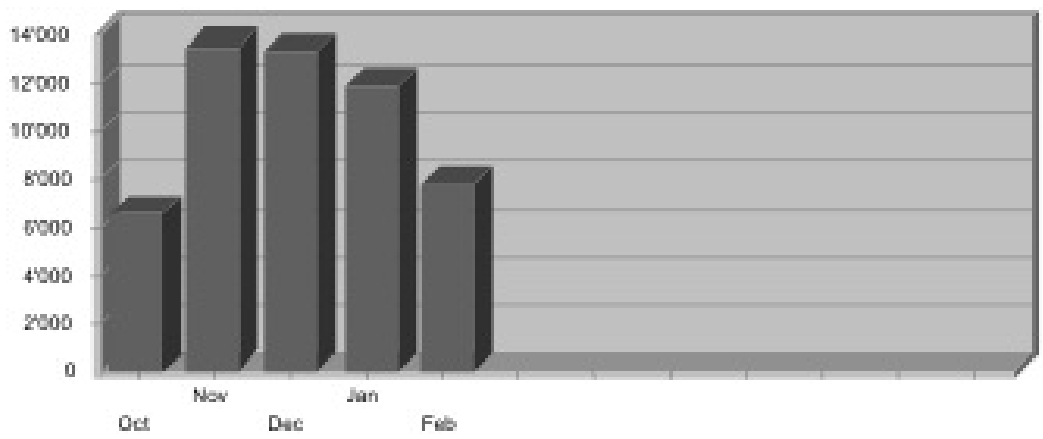

Figure 4: eCF-Basic / BSCW® log-ins per month of all students 


\section{Learning and training material}

Questions: Which learning materials will be mainly used by students? / Which training settings are appreciated?

One hundred sixty one students filled in 2630 students' behavior questionnaires (see Table 3).

Table 3: Students' behavior diary data after each system log out from 161 students ( $N=2630 \log$ out diaries)

\begin{tabular}{|c|c|c|c|}
\hline Over all students' behavior & Activities in total & $\begin{array}{l}\text { Frequency of the acti- } \\
\text { vity per log-in } M\end{array}$ & $\begin{array}{c}\text { Duration of the activity } \\
\text { per log-in (min.) } M\end{array}$ \\
\hline \multicolumn{4}{|l|}{ Autonomous related activities online } \\
\hline Reading learning goals & 950 & 2 & 8 \\
\hline Working on multiple-choice questions & 667 & 4 & 21 \\
\hline Reading assignments & 627 & 2 & 31 \\
\hline Printing text & 598 & 5 & 12 \\
\hline Reading text & 568 & 3 & 33 \\
\hline Excel-simulations & 491 & 3 & 34 \\
\hline Flash-animations & 485 & 3 & 19 \\
\hline Searching for eCF related information & 266 & 2 & 10 \\
\hline Using Media pool & 123 & 2 & 11 \\
\hline Reading FAQ content & 87 & 2 & 7 \\
\hline Looking up words in glossary & 85 & 2 & 10 \\
\hline Reading FAQ technology & 22 & 1 & 5 \\
\hline \multicolumn{4}{|l|}{ Autonomous related activities offline } \\
\hline Reading textbook & 721 & 2 & 108 \\
\hline Reading printed text & 359 & 4 & 63 \\
\hline Excel-simulations offline & 297 & 3 & 40 \\
\hline Working on test task & 240 & 1 & 37 \\
\hline Working on group task & 59 & 1 & 132 \\
\hline \multicolumn{4}{|l|}{ Group related activities online } \\
\hline Reading forum & 1410 & 1 & 9 \\
\hline Sending e-mails & 1164 & 1 & 6 \\
\hline Up / down load files & 402 & 2 & 6 \\
\hline Writing into forum & 251 & 1 & 7 \\
\hline Reading e-mails & 88 & 2 & 5 \\
\hline Writing files comments in BSCW® & 57 & 1 & 5 \\
\hline
\end{tabular}

Looking at the activities related to autonomous online / offline learning, most of the students' activities were related to gathering information (reading learning goals online and textbook offline). These activities were followed by working on multiple-choice questions, printing text online and reading text online. The explorative learning tools such as media pool, glossary and FAQ were seldom used. Thus, students used a more guided learning approach to acquire corporate finance knowledge, which is a sign for their use of autonomy. 
Group activities consisted of mainly reading the forum (gathering information) and sending e-mails (see Table 3). The huge amount of sent e-mails can be explained by the fact that students had to send their individual test tasks to their coaches every second week in order to be accredited to the final exam. The group interactive communication options via BSCW@ were partly used. The relation between reading the forum and writing into the forum was $6: 1$, which means that students were often reading the forum but rarely did write comments or questions into it.

The analysis of the actual BSCW® postings showed that during the semester approximately 3 messages were written by each student and 43 postings by each coach (see Table 4).

Table 4: BSCW® postings during the semester

\begin{tabular}{|c|c|c|c|c|c|c|c|}
\hline Group & $\mathbf{N}$ & Students (all) & Coaches (N=1) & Group & N & Students (all) & Coaches (N=1) \\
\hline 1 & 8 & 73 & 37 & 6 & 11 & 37 & 40 \\
5 & 19 & 41 & 43 & 11 & 11 & - & - \\
7 & 12 & 85 & 80 & 4 & 12 & 49 & 43 \\
3 & 13 & 12 & 30 & 12 & 12 & 16 & 28 \\
8 & 15 & 14 & 25 & 2 & 15 & 93 & 70 \\
10 & 18 & 23 & 35 & 9 & 12 & 33 & 40 \\
\hline
\end{tabular}

Questionnaire results showed that students only partly agree $(M=3.76$, $\mathrm{SD}=1.02)$ with the statement "In the online part interesting discussions occurred» $(1=$ totally agree to $5=$ totally disagree $)$. Coaches rated the aspect of keeping the online discussion as relatively difficult $(\mathrm{Md}=3)$. Only content related questions were more difficult ( $\mathrm{Md}=4 ; 1=$ very low to 3 =very high) to solve.

Students spent most of the time on the group task as a single task, followed by reading the textbook ( 1.5 to 2 hours per session). Students spent approximately half an hour (see Table 3) on online Excel-simulations and Flash-animations. Overall, students worked approximately two hours offline compared to $45 \mathrm{mi}$ nutes online per diary intro.

\section{Students ' exam preparation}

Question: Which materials / settings are used for exam preparation?

A day after the final exam students were asked about their exam preparation behavior. Answers are presented in Table 5. Students often worked with abridged texts, multiple-choice questions, additional texts and class attendance documents. 
Table 5: Final exam preparation, 7 point scale, $1=$ used very often to $7=$ never used, $r=$ correlation with the final exam score, ${ }^{*}=p<.05$

\begin{tabular}{|c|c|c|c|}
\hline Learning materials / settings & M & SD & $\mathbf{r}$ \\
\hline \multicolumn{4}{|l|}{ Autonomous: guided activities } \\
\hline Summarized eCF texts (PDF) & 1.42 & 0.68 & -.06 \\
\hline Multiple-choice questions & 1.79 & 1.09 & -.04 \\
\hline Additional texts for eCF (PDF) & 1.81 & 0.91 & .06 \\
\hline Class attendance documents & 1.81 & 1.13 & $-.24^{*}$ \\
\hline Own summaries and notes & 2.40 & 1.48 & -.07 \\
\hline Excel-simulations & 2.41 & 1.16 & .12 \\
\hline Individual test tasks & 2.96 & 1.42 & .04 \\
\hline Textbook & 3.08 & 1.33 & .06 \\
\hline Flash-animations & 3.13 & 1.39 & .09 \\
\hline \multicolumn{4}{|l|}{ Autonomous: explorative activities } \\
\hline Media pool & 4.57 & 1.52 & -.20 \\
\hline Glossary & 4.72 & 1.50 & -.20 \\
\hline FAQ content & 5.12 & 1.01 & -.09 \\
\hline Literature tips & 5.26 & 1.09 & .03 \\
\hline \multicolumn{4}{|l|}{ Group activities: online / face-to-face } \\
\hline Face-to-face or telephone discussions with student colleagues & 3.28 & 1.54 & .04 \\
\hline BSCW@ forum for the presence part and final exam & 3.87 & 1.53 & -.09 \\
\hline Group task & 4.12 & 1.56 & .13 \\
\hline BSCW® class forum & 4.23 & 1.37 & -.02 \\
\hline Discussions with student colleagues via e-mail & 4.44 & 1.36 & .06 \\
\hline
\end{tabular}

From a blended learning point of view, students made strong use of online material as well as information given face-to-face. Furthermore, Excel-simulations, individual test tasks and the students' own summaries were used quite often. Explorative tools like the media pool, the glossary as well as the FAQ content and the literature tips were rarely used. Students mainly learned for themselves and sometimes discussed with each other topics face-to-face or at the telephone.

\section{Students' Learning outcome}

Question: Are there any relationships between: (a) group activities and the final exam, and / or (b) between students' individual task performance during the semester and the final exam?

No significant differences in learning outcome were found between 12 groups (ANOVA df $=11, \mathrm{f}=1.65, \mathrm{p}<.10$ ) as presented in Table 6 , although active (many postings) and inactive groups could be found. On an individual basis we found a significant correlation $(\mathrm{r}=.29, \mathrm{p}<.01)$ between students' postings and their final exam score (Gerber, 2004).

However, students who were more active in using group activities as part of their exam preparation (see Table 5) did not achieve a better final exam score. For significant tests students were allocated to three groups (highly active / active / passive) and Chi-Squares were always below $\mathrm{p}<.05$. 
Table 6: Final exam scores and BSCW® postings

\begin{tabular}{|c|c|c|c|c|c|}
\hline Group & $\mathrm{N}$ & $\mathrm{M}$ & $\mathrm{SD}$ & $\begin{array}{c}\text { Students' } \\
\text { postings }\end{array}$ & $\begin{array}{c}\text { Coaches' }^{\prime} \\
\text { postings }\end{array}$ \\
\hline 1 & 8 & 5.13 & .61 & 73 & 37 \\
5 & 19 & 5.08 & .63 & 41 & 43 \\
7 & 12 & 4.98 & .83 & 85 & 80 \\
3 & 13 & 4.98 & .67 & 12 & 30 \\
8 & 15 & 4.97 & .60 & 14 & 25 \\
\hline 10 & 18 & 4.83 & .49 & 23 & 35 \\
6 & 11 & 4.70 & .68 & 37 & 40 \\
11 & 11 & 4.70 & .77 & - & - \\
4 & 12 & 4.46 & 1.30 & 49 & 43 \\
12 & 12 & 4.42 & .73 & 16 & 28 \\
2 & 15 & 4.33 & 1.40 & 93 & 70 \\
9 & 12 & 4.27 & 1.00 & 33 & 40 \\
\hline
\end{tabular}

The individual test tasks were developed as knowledge application tasks. These tasks should help students for the exams preparation. Only two significant correlations (task 1 and 7 ) between the seven individual test tasks presented during the semester and the final exam scores could be found (see Table 7). The individual test tasks did not fulfill their purpose.

Table 7: Pearson Correlations between final exam scores and individual test tasks

\begin{tabular}{|c|c|c|c|c|c|c|c|}
\hline Individual test task & 2 & 3 & 4 & 5 & 6 & 7 & Final exam \\
\hline 1 & -.05 & .06 & -.05 & .07 & -.12 & .13 & $.17^{*}$ \\
2 & & $.28^{* *}$ & .05 & $.21^{* *}$ & -.04 & .11 & .08 \\
3 & & & .01 & .10 & .12 & .08 & -.09 \\
4 & & & & .12 & -.05 & .15 & .15 \\
5 & & & & & .06 & .11 & .13 \\
6 & & & & & & -.14 & -.07 \\
7 & & & & & & & $.16^{*}$ \\
\hline
\end{tabular}

Students who invested 120 hours or less on the course achieved lower final marks than students who spent 120 to180 hours. However, students who spent more than 180 hours did not show better scores (Chi-Square, $\mathrm{p}<.05$ ).

\section{Discussion}

Students made use of the availability of the blended learning opportunities around the clock. They learned not too evenly spread at all hours and days of the semester.

The data shows that students choose learning situations which are more related to individual on- and offline learning than to collaborative learning. More 
precisely, they mostly choose the predefined learning paths with defined learning goals, knowledge acquisition, self-testing and finally doing small exercises for receiving accreditation points for the final exam. Coaches tried to integrate all students into content related discussions and collaborative activities with approximately 43 postings, but responses remained small with approximately three postings per student in one semester. A strong individual knowledge construction took place. Coaches could not establish an interactive online community (Slavin, 1995). The discussion forum was seldom used to raise questions or to support each other during the semester. However, it was used to get information. A theory-based (e. g. Greeno, 1997) task development of online group tasks and activities does not necessarily lead to the use of the tasks, if students have several choices. Students did not restrict their individual autonomy to enlarge collective autonomy for example by working more collaboratively. The blended learning course was more used like a traditional eLearning course than a hybrid course.

Two chains of arguments can explain these findings: first situational and second personal.

The situational perspective assumes that task accomplishment at an on-campus university takes place face-to-face. Students meet face-to-face in order to discuss content related and private questions. The meetings are an important social event. First empirical hints can be found in the fact that students used more faceto-face settings or the telephone than $\mathrm{BSCW}{ }^{\circledR}$ for the final exam preparation.

From a personal point of view, the process oriented motivation VIE-model (Vroom \& Yetton, 1973) might help to understand students' behavior. Motivation consists of expectancy, instrumentality and valence. Expectancy is the estimated relationship between an action or effort (e.g. learning with online material) and a performance (e.g. factual knowledge development / communication skills). Instrumentality is the perceived probability that a particular performance (e.g. factual knowledge / communication skills) will lead to other reward (e.g. pass the final exam).Valence is the value or expected utility for a particular outcome (e.g. to pass the final exam). Students might have assessed which activity (working with textbook, active involvement in online cooperation etc.) will lead more efficiently to a successful exam. It might be possible that for the students group activities had a lower value with respect to their expectancy of gaining factual knowledge and a higher level of learning social skills. The students' may have perceived social skills as having a lower instrumentality value than factual knowledge development for passing the exam. These preconditions would lead to the decision to follow the outlined learning path as the most appropriate way to pass the exam efficiently.

From a teaching point of view, different interventions might improve interactivity:

1. Reduce students' autonomy by developing tasks which must be solved only in the online discussion-forum. For example, foster students to post theoretical papers which criticize the previous autonomously learned theory in the on- 
line forum. Students will be forced to work on the identified contradictions in online groups.

2. Implement a problem-solving-skills test in the final exam. Analogous to the first point, students will be encouraged to discuss a case study as critical as possible in online discussions in order to achieve a qualification in problemsolving-skills, which will be tested in the final exam.

3. Develop complex real life problem tasks, where communication processes are necessary for task accomplishment (Schröder \& Wankelmann, 2002).

Even though the motivational aspect of using online tools for cooperation is relevant, we must consider that in many cases the real use of new learning settings is often below expectations (Dillon \& Gabbard, 1998; Gräsel, Fischer \& Mandl, 2001).

Additionally, Martinez and Sweger (1996) and Sturgill, Martin and Gay (1999) showed that computer experience is significantly related to intensive use of online cooperation tools. This leads us to speculate that the students in this study had not had enough experience in computer supported cooperation (see students profile) in order to make sufficient use of the tools.

From a broader competence perspective, a low level of self-learning competence (Friedrich \& Mandl, 1997; Hartley \& Bendixen, 2001) might be the reason for the strong individual learning behaviour. This is in line with our findings that students did not make use of the eCF-options to explore the learning content. Reinmann-Rothmeier (2003) emphasised the increase of necessary competences to use blended learning settings. In this context our data might indicate a need of training for self-organized learning.

The link of autonomous, group and class attendance learning situations are an innovative and challenging project which merges situational aspects, personal motivation and individual skills. For future blended learning scenarios, a more situated scenario with fewer learning settings and materials might help to increase the students use and to reduce costs: Less is more! The use of CSCL at oncampus universities should be well reflected. Offering students many different learning paths particularly makes sense if the students have self-learning competences and if there is a clear relation between these paths and the final exam or the ECTS. Self-learning is getting more and more popular at schools and universities and right now we are in a transition phase from strong black board teaching to more self-organized learning. In the near future students should be better prepared to make use of the blended learning opportunities.

\section{Acknowledgment}

The authors like to thank the eCF-get involved team for their constructive cooperation and their willingness to critical self-assessment and evaluation. 


\section{Literature}

Bain, J. D. (2003). Slowing the pendulum: Should we preserve some aspects of instructivism? In P. Barker \& S. Rebelsky (ed.), Proceedings of ED-MEDIA 2003 (pp. 1382-1288). Norfolk, VA: Association for the Advancement of Computing in Education.

Brink, M. \& Windlinger, L. (2001). Web-basiertes Lernen. Recherche und Trendbericht. Zollikofen: Schweizerisches Institut für Berufspädagogik.

Clark, R.E. (1994). Media will never influence learning. Educational Technology Research and Development, 42, (2), 21-29.

Clark, R. E. (2001). Learning from media: Arguments, Analysis, Evidence. Greenwich CT: Information Age Publishers Inc.

Cooper, G. (1997). Research into cognitive load theory and industrial design at UNSW. [http://www.arts.unsw.edu.au/schools/education/CLT_NET_ug_97_HTML]. (12.03.1999).

Cuban, L. (2001). Oversold and underused: Computers in the classroom. Cambridge: Harvard University Press.

Dede, C., Salzman, M.C., Loftin, B.R. \& Sprague, D. (1999). Multisensory immersion as a modeling environment for learning complex scientific concepts. In W. F. B. H. N. Roberts (Hrsg.), Computer Modeling and Simulation in Science and Mathematics Education (S. 282319). New York: Springer.

Dillon, A. \& Gabbard, R. (1998). Hypermedia as an educational technology: A review of the quantitative research literature on learner comprehension, control and style. Review of Educational Research, 68, (3), 322-349.

Edelmann, W. (1996). Lernpsychologie. (5 Aufl). Weinheim: Psychologie Verlags Union.

Emery, F. E. (1959). Characteristics of socio-technical systems. Tavistock Institute of Human Relations (Document No. 527).

Engeström, Y. (1999). Lernen durch Expansion.Marburg: BdWi.

Friedrich, H. F. (2000). Selbstgesteuertes Lernen - sechs Fragen, sechs Antworten. [http://www.learnline.nrw.de/angebote/selma/medio/grundlegendes/vortraegeaufsaetze /friedrich/friedrich.pdf] (23.07. 2002).

Friedrich, H. F. \& Mandl, H. (1997). Analyse und Förderung selbstgesteuerten Lernens. In Weinert, F. W. (Hrsg.), Enzyklopädie der Psychologie: (Serie 1), Pädagogische Psychologie, Psychologie der Erwachsenenbildung (Band 4) (S. 237-293). Göttingen: Hogrefe.

Gerber, M. (2004). Online Realität: Tele-tutoring und Studentenleistung in einem blended learning Kurs. Bern: Universität Bern (Unveröffent. Liz.).

Gräsel, C., Fischer, F. \& Mandl, H. (2001). The use of additional information in problemoriented learning environments. Learning Environments Research, 3, 286-305.

Greeno, G.J. (1998). The situativity of knowing, learning and research. American Psychologist, 53, (1), 5-26.

Grote, G. (1997). Autonomie und Kontrolle: zur Gestaltung automatisierter und risikoreicher Systeme. Zürich: vdf.

Grund, S., Gerber, M. \& Grote, G. (2003). eCF-Abschlussevaluationsbericht Wintersemester 02/03. Report. Institute of Work Psychology. ETH Zurich.

Grund, S. \& Grote, G. (1999). Auswirkungen einer virtuell-gegenständlichem Lernumfeld auf Wissen und Problemlösen. Arbeit, 3, 312-317.

Grund, S., Grote, G. \& Windlinger, L. (2003). CIELT - Concept and Instruments for Evaluation of Learning Tools. Report. Institute of Work Psychology, ETH Zurich.

Grund, S., Windlinger, L. \& Grote, G. (2002). «Wunsch» und «Wirklichkeit» in der Nutzung eines webbasierten Kurses an einer Universität. In M. Herczeg, H. Oberquelle \& W. Prinz (Hrsg.), Mensch \& Computer 2002 (S. 175-184). Hamburg: Teubner.

Hartley, K. \& Bendixen, L.D. (2001). Educational research in the internet age: Examining the role of individual characteristics. Educational Researcher, 30, (9), 22-26. 
Horton, W. K. (2000). Designing web-based training. How to teach anyone anything anywhere anytime. New York: Wiley.

Kerres, M. (2002). Online- und Präsenzveranstaltungen in hybriden Lernarragements kombinieren. In A. Hohenstein \& K. Wilbers (Ed.), Handbuch eLearning. Köln: Fachverlag Deutscher Wirtschaftsdienst.

Kirkpatrick, D.L. (1987). Evaluation. In R.L. Craig (Ed.), Training and development handbook (3rd ed.), 301-319. New York: McGraw-Hill.

Kozma, R.B. (1991). Learning with media. Review of Educational Research, 61,(2), 179-212.

Kozma, R.B. (1994). A Reply: Media and Methods. Educational Technology Research and Development, 42, (3), 11-14.

Mandl, H. \& Reinmann-Rothmeier G. (2000). Lernen mit neuen Medien.[http://www.computerphilologie.uni-muenchen.de/jg00/mandl.html]. (25.02.2003).

Martinez, R. \& Sweger, R. (1996). Plugged in: Long distance technology offers benefits and drawbacks to teacher education programs. Vocational Educational Journal, 71, (3), 47-59.

Merrill, M.D. (2002). A pebble-in-the-pond model for instructional design. Performance Improvement, 41,(7), 39-44.

Mousavi, S.Y., Low, R., Schweller, J. (1995). Reducing cognitive load by mixing auditory and visual presentation modes. Journal of Educational Psychology, 87, 319-334.

Lehtinen, E., Hakkarainen, K., Lipponen, L., Rahikainen, M. \& Muukkonen, H. (2002). Computer supported collaborative learning: A review. [http://www.kas.utu.fi/papers/cinet/cinetreport.html]. (14.11.2002).

Nielsen, J. (1994). Usability Engineering. San Francisco: Morgan Kaufmann.

Picciano, A.G. (2002). Beyond student perceptions: Issues of interaction, presence and performance in an online course. Journal of Asynchronous Learning Networks, 6, (1), 21-40.

Reigeluth, C. M. (1999). Instructional design theories and models: A new paradigm of instructional theory. Mahwah, New York: Lawrence Erlbaum Associates.

Reinmann-Rothmeier, G. (2003). Didaktische Innovation durch Blended Learning. Bern: Hans Huber Verlag.

Russell, T.L. (1999). The no significant difference phenomenon.Montgomery: IDECC. [http://teleeducation.nb.ca/nosignificantdifference/]. (24.02.24).

Sauter, W. (2002). Blended learning. Effiziente Integration von eLearning und Präsenztraining. Neuwied: Luchtermann.

Salmon, G. (2000). E-Moderating - The key to teaching and learning online. London: Kogan Page.

Scholz, C. (2002). Blended learning. [http://wissensplanet.com/wissensplanet/file/91391/] (05.01.2002).

Schröder, R. \& Wankelmann, D. (2002). Theoretische Fundierung einer eLearning Didaktik und der Qualifizierung von e-Tutoren.[http://www.rudolf-schroeder.de/download/p-etutuor-1d.pdf] (06.01. 2003).

Shea, P., Fredericksen, E., Pickett, A., Pelz, W. \& Swan, K. (2000). Measures of learning effectiveness in the SUNY learning network. [tlt.suny.edu/ALNWorkshop2000.doc] (24.03. 2002).

Slavin, R.E. (1995). Cooperative learning: Theory, research and practice. Boston: Pearson International.

Skinner, B.F. (1958). The science of learning and the art of teaching. The Harvard Educational Review, 24, (2), 86-97.

Sturgill, A., Martin, W. \& Gay, G. (1999). Surviving technology: A study of student use of computer-mediated communication to support technology education. International Journal of Educational Telecommunications, 5, (3), 239-259.

Swan, K., Shea, P., Fredericksen, E., Pickett, A., Pelz, W. \& Maher, G. (2000). Building knowledge, building communities: consistency, contact and communication in the virtual classroom. Journal of Educational Computing Research, 23, (4), 359-383. 
Trier, K.K. (1999). Comparison of the effectiveness of web-based instruction to oncampus instruction. [http://as1.ipfw.edu/99tohe/presentations/trier.htm]. (06.07. 2002).

Valiathan, R. (2002). Designing a blended learning solution.[http://www.ksb.niit.com/ content/Resources/pdf/Designing\%20a\%20Blended\%20Learning\%20Solution.pdf]. (05.10.2003).

Vroom, V.H. \& Yetton, P. (1973). Leadership and Decision-Making.Pittsburgh: University of Pittsburgh Press.

Weidenmann, B. (1993). Psychologie des Lernens mit Medien. In A. Krapp, B. Weidenmann, M. Hofer, G.L. Huber \& H. Mandl (Hrsg.), Pädagogische Psychologie (S. 493-554). Weinheim: Psychologie Verlags Union.

Weidenmann, B. (1997). Multicodierung und Multimodalität im Lernprozess. In L. J. Issing \& P. Klimsa (Hrsg.), Information und Lernen mit Multimedia (S. 65-84). Göttingen: Hogrefe.

Zimmer, B.J. (1990). Self-regulate learning and academic achievement: An overview. Educational Psychologist, 25, (1), 3-17.

Key words: computer, didactics, evaluation, finance, information and communications technology, learning, teaching method, test, university

\section{Pädagogische Ziele, Kursmerkmale und ihre Beziehung zum Verhalten von Studierenden: Eine Fallstudie zum blended learning.}

\section{Zusammenfassung}

Eine explorative Studie in Corporate Finance wird vorgestellt. Eine detaillierte Beschreibung der konkreten Nutzung von unterschiedlichen Trainingsmaterialien (Bücher / Simulationen / Selbsttestung) und Szenarien (online / offline / individuelles / Gruppen-Lernen) wird gegeben. Dies ist eine der ersten blended learning Studien, die verschiedene Evaluationsmethoden in eine systematische Analyse von Benutzerverhalten integriert. 161 Studierende füllten einen Nutzerprofilfragebogen und ein Nutzertagebuch nach jedem Ausloggen aus und bearbeiteten eine Abschlussklausur und einen Prüfungsvorbereitungsfragebogen. Zusätzlich wurden log file Daten erhoben. Die Ergebnisse zeigen, dass Studenten insbesondere mit Texten, Selbsttestaufgaben und Excel-Simulationen arbeiteten und weniger interaktive Gruppenelemente nutzten. Wir schlussfolgern, für die weitere Entwicklung von blended learning Kursen mehr auf interaktives Material zu fokussieren, eine klare Verbindung zwischen Multiple-Choice-Aufgaben und der Prüfung herzustellen und die Studierenden in der effizienten Nutzung von blended learning Konzepten zu unterrichten.

Schlagworte: Computer, Didaktik, Evaluation, Finanzwissenschaft, Hochschule, Informations- und Kommunikationstechnologie, Lernen, Test, Unterrichtsmethode 


\section{Objectifs pédagogiques et caractéristiques de cours en relation avec le comportement des étudiants: Une étude de cas sur l'apprentissage mixte}

\section{Résumé}

L'article présente une étude exploratoire dans le domaine de la finance d'entreprise. L'usage actuel de divers matériaux d'enseignement hybride (livres / simulations / auto évaluation) et des scénarios (en ligne / autonome / apprentissage individuelle / en groupe) est décrit de manière détaillée. L'étude présentée est l'une des premières qui intègre des méthodes différentes dans une approche systématique de l'analyse du comportement des étudiants. Un échantillon de 161 étudiants ont rempli un questionnaire sur le profil utilisateur et ont utilisé un journal en ligne qui décrit le comportement des étudiants après chaque log out du système. Ils ont également passé un examen et rempli un questionnaire final. Les résultats de la collecte des données du fichier journal indiquaient que les étudiants ont préféré apprendre avec des textes, des exercices d'autoévaluation et des simulations sur tableur Excel plutôt qu'en utilisant un forum interactif de discussion concernant les scénarios d'apprentissage ouverts. La conclusion souligne qu'en ce qui concerne l'enseignement hybride, il est nécessaire de se concentrer sur le matériau interactif, de lier des tests de choix multiples avec l'examen final et d'habituer les étudiants à utiliser les concepts de l'enseignement hybride avec efficience.

Mots clés: acquisition de connaissances, didactique, enseignement, évaluation, finance internationale, ordinateur, technologie de l'information et de la communication, test, université

\section{Obiettivi pedagogici e caratteristiche di un corso in relazione con il comportamento degli studenti: uno studio di caso di blended learning}

\section{Riassunto}

Si presenta uno studio esplorativo nell'ambito della Finanza Aziendale ove si da una descrizione dettagliata dell'utilizzo concreto di vari materiali (libri, simulazioni, autoesami) e scenari (online / offline / apprendimento individuale / in gruppo) formativi. Si tratta di una delle prime indagini di apprendimento integrato ('blended learning') che combini vari metodi di valutazione in un'analisi sistematica del comportamento degli utenti. Dopo ogni chiusura delle sessioni, 161 studenti hanno compilato un questionario sul profilo dell'utente e scritto un diario dell'utente; hanno inoltre svolto un esame finale e compilato un questionario di preparazione all'esame. In più sono stati raccolti dati dai log file. I risultati mostrano che gli studenti lavorano più con testi, esercizi di autoesame e si- 
mulazioni Excel, mentre utilizzano meno elementi interattivi di lavoro di gruppo. Ne deduciamo che per un successivo sviluppo di corsi di 'blended learning' si debba: focalizzarsi maggiormente su materiale interattivo, stabilire una chiara connessione fra esercizi di 'multiple choice' ed esame finale ed insegnare agli studenti l'utilizzo efficiente dei concetti di 'blended learning'.

Parole chiave: apprendimento, computer, didattica, finanza, metodo di insegnamento, tecnologie dell'informazione e della communicazione, test, valutazione, università 